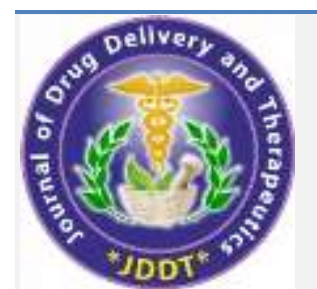

SDDT

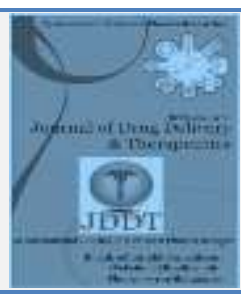

Research Article

Open Access Full Text Article

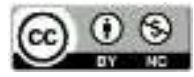

\title{
Antioxidant and Antidiabetic activity of hydroalcoholic flower extract of Woodfordia fruticosa (L.) Kurz
}

\author{
Simran Giri, Ganesh Dey, Tarun Kumar Dua* (i) \\ Department of Pharmaceutical Technology, University of North Bengal, Raja Rammohunpur, P.O.- NBU, District- Darjeeling, Pin- 734013, West \\ Bengal, India
}

\begin{tabular}{ll}
\hline Article Info: & \\
& Article History: \\
& $\begin{array}{l}\text { Received 11 November 2021 } \\
\text { Accepted 20 December 2021 }\end{array}$ \\
&
\end{tabular}

Cite this article as:

Giri S, Dey G, Dua TK, Antioxidant and Antidiabetic activity of hydroalcoholic flower extract of Woodfordia fruticosa (L.) Kurz, Journal of Drug Delivery and Therapeutics. 2022;

12(1):1-6

DOI: http://dx.doi.org/10.22270/jddt.v12i1.5247

\section{*Address for Correspondence:}

Dr. Tarun Kumar Dua, Department of Pharmaceutical Technology, University of North Bengal, Raja

Rammohunpur, P.O.- NBU, District- Darjeeling, Pin- 734013, West Bengal, India

ORCID ID: https://orcid.org/0000-0001-5136-7564

\section{Abstract}

Woodfordia fruticosa (L.) Kurz, (W. fruticosa) a member of the Lythraceae family, commonly known as dhaiphul, has been used in traditional medicine to cure common illnesses since ancient times. The most effective part of this plant is the flower which has a high demand in the national as well as the international market of the eastern south part of Asian countries. The present study focuses on exploring the presence of phytochemicals, antioxidants, and antidiabetic potential of hydroalcoholic extract of flower of $W$. fruticosa. Phytochemical test showed the presence of saponin, flavonoid, carbohydrates, alkaloids, tannin, anthraquinone, and triterpenoids in the extract, and it showed an effective result of total phenolic content, total flavonoid Content with the value of $371.96 \pm 2.86 \mathrm{mg}$ of gallic acid equivalent per gram of the extract and $113.82 \pm 0.178$ $\mathrm{mg}$ of quercetin equivalent per gram of dry weight. In vitro antioxidant assay, for the DPPH assay, the $\mathrm{IC}_{50}$ values were found $30.85 \pm 0.36 \mu \mathrm{g} / \mathrm{ml}$ and $22.35 \pm 0.54 \mu \mathrm{g} / \mathrm{ml}$ for the extract of $W$. fruticosa flower and ascorbic acid respectively and for the FRAP Assay, the reducing power assay of plant extract is lesser than standard (Ascorbic acid). $W$. fruticosa also showed significant hyperglycemic activity. In accordance with results, we can conclude that plant consists of a high polyphenolic and flavonoid group which help in antioxidant activity as well as the hydroalcoholic extract shows mild activity against diabetes.

Keywords: Woodfordia fruticosa, phytochemical, hydroalchoholic, antioxidants, antidiabetic, DPPH.

\section{INTRODUCTION}

Since primitive times, the plant has been used for many purposes in household stuff, dietary supplement as well as medicine. Furthermore, over $80 \%$ populations of developing nations usually look upon herbal medicine for their basic health needs according to WHO (World Health Organization) instead of allopathic medication ${ }^{1}$. The plant consists of phytochemicals as primary metabolite and secondary metabolite, where the medicinal properties were mainly exhibited by secondary metabolite which contained the compound like phenol, flavonoid, etc, which play important role in defensive nature of plant as well as contain various antioxidants which are helpful for human health by preventing disease ${ }^{2}$. The plants have the potential for antidiabetic activity because of the presence of secondary metabolites (myricetin, kaempferol, Apigenin, Quercetin, etc), which have activity against those enzymes which are responsible for the disturbance of harmony of glucose level in the body ${ }^{3}$.

Woodfordia fruticosa (L.) Kurz (Family: Lythraceae) (W. fruticosa) is a fully matured plant, mostly available in the high altitude of the subtropical region of the southern part of Asian countries like China,Nepal, India, and in a few places of Africa continent like Comores, Madagascar, and E-Tanzania4. The main phytochemicals found in the $W$. fruticosa are tannins, polyphenolic groups, and flavonoids, and other chemical constituents are saponins, essential oil, carbohydrate etc ${ }^{5}$. According to previous researches $W$. fruticosa flowers extract has anti-inflammatory ${ }^{6}$, gastroprotective ${ }^{7}$, hepatoprotective $^{8}$, antioxidant ${ }^{9}$, Alzheimer's disease ${ }^{10}$, and wound healing activity ${ }^{11}$. The main objective of this work was to explore the phytochemical profile, antioxidant activity, and in vitro anti-diabetic properties of the $W$. fruticosa flower.

\section{MATERIAL AND METHODS}

\section{Plant materials}

The flowers of $W$. fruticosa have been collected from the Sevok, (District: Darjeeling) West Bengal in April and May in 2020. The plant was authenticated (Reference no. CNH/Tech.II/2021/11) by the Botanical Survey of India, Shibpur, Howrah (West Bengal). This plant specimen has been preserved in the laboratory for further reference.

\section{Preparation of the extract}

The flowers of the $W$. fruticosa were dried under shade and after the drying; the material is smashed into powder form of mesh 40 with the help of a mechanical grinder. The 
resulted powder was subjected to maceration process with hydroalcoholic solvent [Ethanol and water (70:30)]. The hydroalcoholic extract of $W$. fruticosa (HAWF) was filtered and get concentrated by a rotary vacuum evaporator under pressure. For further dryness and storage, it was kept in a desiccator for the experiments to be performed.

\section{Phytochemical Screening}

The phytochemical screenings were done with the HAWF for the qualitative analysis of phytochemicals present in the $W$. fruticosa flower. The standard protocol was used for the test for carbohydrates, alkaloids, flavonoids, tannins, triterpenoids, glycosides, and saponins as per 12-13.

\section{Determination of Total Phenolic Content (TPC)}

A stock solution of standard and extract was prepared in a concentration of $1 \mathrm{mg} / 1 \mathrm{ml}$ in distilled water from which 0.4 $\mathrm{ml}$ of sample/standard was withdrawn into the test tube and then, $0.4 \mathrm{ml}$ Folin-ciocalteu reagent and $4 \mathrm{ml}$ distilled water was added to samples, which was incubated for 5 minutes in the dark place. After $5 \mathrm{~min}, 4 \mathrm{ml}$ 7\% Sodium carbonate solution was added in each tube, and volume makeup was done up to $10 \mathrm{ml}$ by distilled water, which was further incubated in a dark place for 90 minutes at room temperature. Measurement of the absorbance was taken at $730 \mathrm{~nm}$ using distilled water as blank and gallic acid as standard. A Calibration curve was made with gallic acid concentrations in the range of $(10,50,100,200,400$, and 800 $\mu \mathrm{g} / \mathrm{ml}$ ). Total phenolic content was stated in mg gallic acid equivalents (GAE) per gram of dry weight ${ }^{14}$.

\section{Determination of Total Flavonoid Content (TFC)}

The aluminum chloride colorimetric assay was performed to determine the total flavonoid content of the extract. Stock solution of standard and HAWF was prepared in a concentration of $1 \mathrm{mg} / 1 \mathrm{ml}$ in methanol from which $0.2 \mathrm{ml}$ of $10 \%(\mathrm{w} / \mathrm{v})$ solution in methanol was added in each sample/standard. Thereafter, $0.2 \mathrm{ml}$ of $1 \mathrm{M}$ Potassium acetate solution was added and then, 5.6 ml of distilled water was added to volume makeup which will incubate for $30 \mathrm{~min}$ at room temperature. Measurement of the absorbance was taken at $415 \mathrm{~nm}$ using, Methanol as blank and Quercetin as standard. A calibration curve was made with quercetin concentration in the range of $(10,50,100,200$, and $400 \mu \mathrm{g} / \mathrm{ml}$ ). The total flavonoid content was expressed as quercetin equivalents per gram of dry weight 15 .

\section{Determination of In Vitro Antioxidant Activity}

\section{DPPH Free Radical Scavenging Activity}

The free radical scavenging activity of HAWF was measured by using DPPH (1, 1-diphenyl-2-picryl-hydrazil). Stock was prepared in $1 \mathrm{mg} / 1 \mathrm{ml}$ Methanol for extract and standard. Dilution was done with $(10,25,50,125$, and $200 \mu \mathrm{g} / \mathrm{mL})$ in which $1 \mathrm{ml}$ DPPH (concentration $0.3 \mathrm{mM}$ ) solution was added in each sample which was incubated for $30 \mathrm{~min}$ in dark at room temperature. After that, Measurement of the absorbance at $517 \mathrm{~nm}$ was taken by spectrophotometer, where methanol was blank and $1 \mathrm{ml}$ DPPH solution as a control. The scavenging activity of DPPH was calculated with the formula:

$\%$ DPPH scavenging activity or (\% inhibition $)=\left[1-\frac{A b s(s)}{A b s(c)}\right] \times$ 100

Where $\operatorname{Abs}(\mathrm{c})$ is the absorbance of the control and $\mathrm{Abs}(\mathrm{s})$ is the absorbance of standard/sample.

The IC 50 (inhibitory concentration) is calculated by plotting the percentage of inhibition against concentration $(\mu \mathrm{g} / \mathrm{ml})^{16}$.

\section{Ferric Reducing Antioxidant Power (FRAP)}

The reducing power assay of the HAWF was calculated by using potassium ferricyanide. Stock of $1 \mathrm{mg} / \mathrm{ml}$, extract, and standard (Ascorbic acid) was prepared in methanol. Dilution of stock was done with methanol in the concentration of 100-300 $\mu \mathrm{g} / \mathrm{ml}$, in which $2.5 \mathrm{ml}$ of Phosphate buffer (pH-6.6, $0.2 \mathrm{M}$ ) and $2.5 \mathrm{ml}$ of $1 \%$ potassium ferricyanide was added. Shake the above solution properly and incubate it in the water bath at $50^{\circ} \mathrm{C}$ for 25 minutes. After incubation, the solution was allowed to cool down and then, $2.5 \mathrm{ml}$ of $10 \%$ Trichloroacetic acid was added to the respective solution which will be placed in a vortex for well mixing. From the above mixture, $2.5 \mathrm{ml}$ of solution was pipette out and diluted with $2.5 \mathrm{ml}$ of distilled water respectively. At last $0.5 \mathrm{ml}$ of $0.1 \%$, Ferric chloride was added and then mixed. The absorbance of the solution was measured at $700 \mathrm{~nm}$. The blank solution contains everything except standard/ extract $^{17}$.

\section{In vitro Antidiabetic activity}

\section{$\alpha$-amylase Inhibition Assay}

For the determination of $\alpha$-amylase inhibition assay of $W$. fruticosa initially, a stock solution of $1 \mathrm{mg} / \mathrm{ml}$, extract or acarbose was prepared in sodium phosphate buffer $(0.02 \mathrm{M}$ and $\mathrm{pH} 6.9$, which was maintained by $0.006 \mathrm{M} \mathrm{NaCl}$ solution). The dilution of stock was done in the concentration of $100-1000 \mu \mathrm{g} / \mathrm{ml}$ from which $500 \mu \mathrm{l}$ was withdrawn from each dilution tube mixed with $500 \mu \mathrm{l}$ of $\alpha$ amylase solution $(13 \mathrm{U} / \mathrm{ml})$ and thus, the mixture of the tube was kept for incubation at $37^{\circ} \mathrm{C}$ for 30 minutes. After this, $500 \mu \mathrm{l}$ of $1 \%$ starch solution was added to each tube and incubated at $37^{\circ} \mathrm{C}$ for 10 minutes. $1 \mathrm{ml}$ DNSA solution was added to each tube and thus, the tube was set down for boiling at water bath for $10 \mathrm{~min}$ to stop the reaction. After the tubes get cooled down, $10 \mathrm{ml}$ distilled water was added to the tube, and absorbance were measured at $540 \mathrm{~nm}$ using Phosphate buffer as blank and 100\% enzyme activity solution (except sample/ standard, everything was added) as control. The percentage of inhibition for $\alpha$-amylase activity was calculated by the below equation:

$\%$ inhibition $=\left[1-\frac{A b s(s)}{A b s(c)}\right] \times 100$

Where $\operatorname{Abs}(\mathrm{c})$ is the absorbance of the control and $\mathrm{Abs}(\mathrm{s})$ is the absorbance of standard/sample. IC $_{50}$ represents sample concentration $(\mu \mathrm{g} / \mathrm{ml})$ required to decrease the activity of biological function of compound ${ }^{18-19}$.

\section{$\alpha$-glucosidase Inhibition assay}

For the determination of the $\alpha$-glucosidase inhibitory activity of plant $W$. fruticosa initially, the stock solution of $1 \mathrm{mg} / \mathrm{ml}$, of extract or acarbose was prepared in sodium phosphate buffer $(100 \mathrm{mM}, \mathrm{pH} 6.8)$ from which dilution was made from $100-500 \mu \mathrm{g} / \mathrm{ml} .100 \mu \mathrm{l}$ from each dilution tube was withdrawn in which $40 \mu \mathrm{l} \alpha$-glycosidase $(1 \mathrm{U} / \mathrm{ml})$ solution was added and then kept for incubation at $37^{\circ} \mathrm{C}$ for 20 minutes. After preincubation, $70 \mu \mathrm{l} 5 \mathrm{mM}$ PNPG (paranitrophenyl- beta glucopyranoside) which was made with buffer was added and again incubation was done at 37 o $\mathrm{C}$ for 60 minutes. $2.5 \mathrm{ml} 0.1 \mathrm{M} \mathrm{Na}_{2} \mathrm{CO}_{3}$ solution was added in each tube to stop the reaction and thus, absorbance was measured at $400 \mathrm{~nm}$ using Phosphate buffer as blank and $100 \%$ enzyme activity solution (except sample/ standard, everything was added) as control. The percentage of inhibition for $\alpha$-glucosidase activity was calculated by the below equation:

$\%$ inhibition $=\left[1-\frac{A b s(s)}{A b s(c)}\right] \times 100$ 
Where $\operatorname{Abs}(c)$ is the absorbance of the control and $A b s(s)$ is the absorbance of standard/sample. $\mathrm{IC}_{50}$ represents sample concentration $(\mu \mathrm{g} / \mathrm{ml})$ required to decrease the activity of biological function of compound $20-21$.

\section{Statistical analysis}

The experiment was conducted by taking each concentration in a triplicate. All values were presented as mean \pm standard deviation. Data were statistically calculated by utilizing oneway ANOVA followed by Dunnett's t-test.

\section{RESULTS AND DISCUSSION}

\section{Phytochemical screening}

The phytochemical analysis showed the presence of several chemical groups like flavonoids, alkaloids, carbohydrates, tannins, glycosides, triterpenoids, and saponins in HAWF.

\section{Determination of total phenolic content}

The total phenolic content of HAWF was assessed byutilizing Folin-Ciocalteu method where this reagent is formed by the mixture of two compounds is phosphotungstic acid and phosphomolybdic acid which oxidize to blue color in presence of phenol group; the blue color is due to the reduction of acid into tungsten and molybdenum. Gallic acid was used as standard and hence, a calibration curve (Figure 1) of the standard was established. The phenolic compound content was determined as gallic acid equivalents using the following linear equation based on the calibration curve: $A=$ $0.0022 C-0.0143, \mathrm{R}^{2}=0.9988$. $A$ is the absorbance, and $C$ is gallic acid equivalents $(\mu \mathrm{g})$. The total phenolic content of the extract was expressed as mg of gallic acid equivalent per gram of dry weight of the extract. The level of total polyphenolic compounds was $671.96 \pm 5.6$ of gallic acid equivalent per gram of the extract.

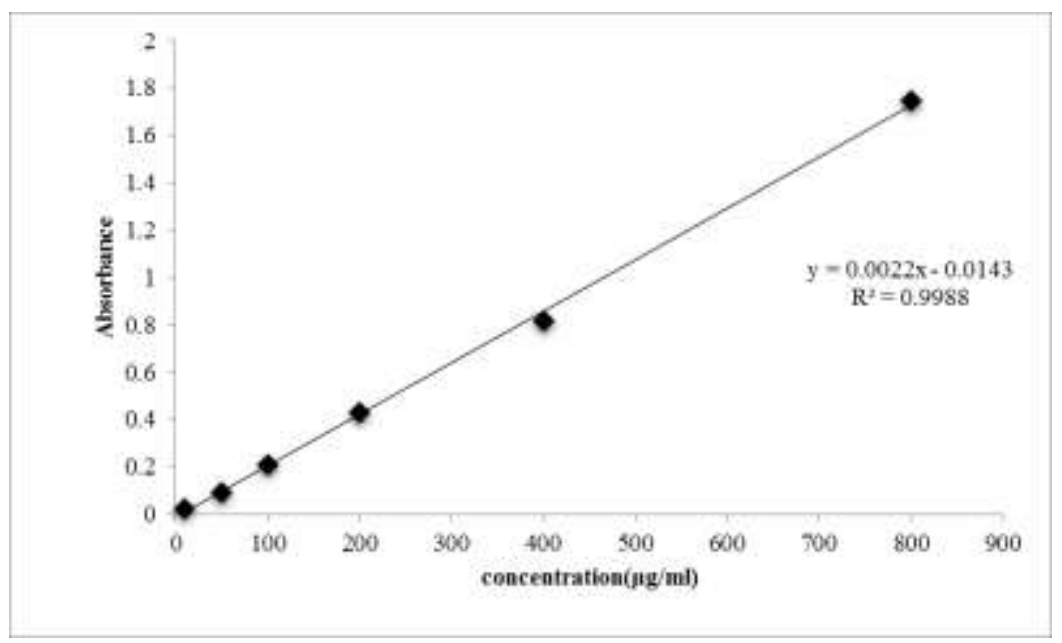

Figure 1: Calibration curve of gallic acid

\section{Determination of total flavonoid content}

The total flavonoid content of HAWF was assessed by utilizing the aluminum chloride colorimetric method, where this reagent forms a complex with flavones and flavonol which can be easily detected at $415 \mathrm{~nm}$ in a UV spectrophotometer. Quercetin was used as a standard whose calibration curve (Figure 2) was established. Linear equation based on the calibration curve is: $A=0.0034 C+0.06, \mathrm{R} 2=$ $0.9974 . A$ is the absorbance, and $C$ is quercetin equivalents $(\mu \mathrm{g} / \mathrm{ml})$. The total flavonoid content of the extract was found to be $113.82 \pm 0.178 \mathrm{mg} / \mathrm{g}$ of quercetin equivalent per gram of dry weight.

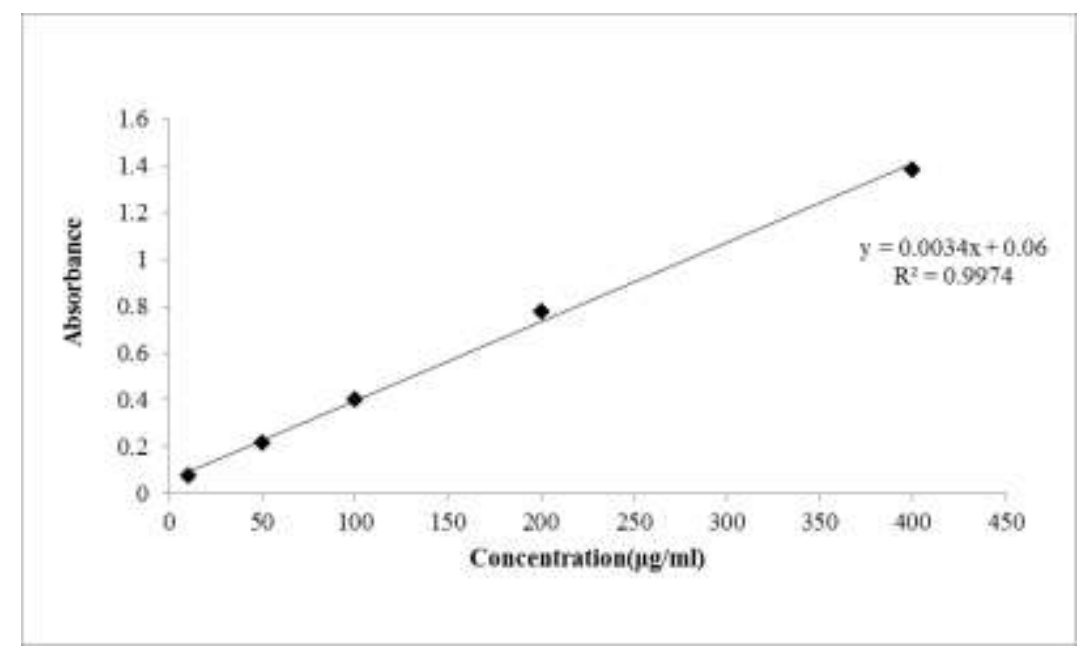

Figure 2: Calibration curve of quercetin. 


\section{Determination of In Vitro Antioxidant Activity}

\section{DPPH Free Radical Scavenging Activity}

This assay helps in the detection of the reduction of DPPH, where DPPH is reduced to $\mathrm{DPPH}_{2}$ due to the presence of an antioxidant compound present in the extract, and because of this, the decolorization occurs, which can be easily detected in absorbance at $517 \mathrm{~nm}$. Figure 3 represents the graph between the percentage of inhibition and concentration, which shows a constant increment in scavenging property of plant extract and reference standard i.e. Ascorbic acid. The $\mathrm{IC}_{50}$ values were found to be $30.85 \pm 0.36 \mu \mathrm{g} / \mathrm{ml}$ and $22.35 \pm$ $0.54 \mu \mathrm{g} / \mathrm{ml}$ for HAWF and ascorbic acid respectively.

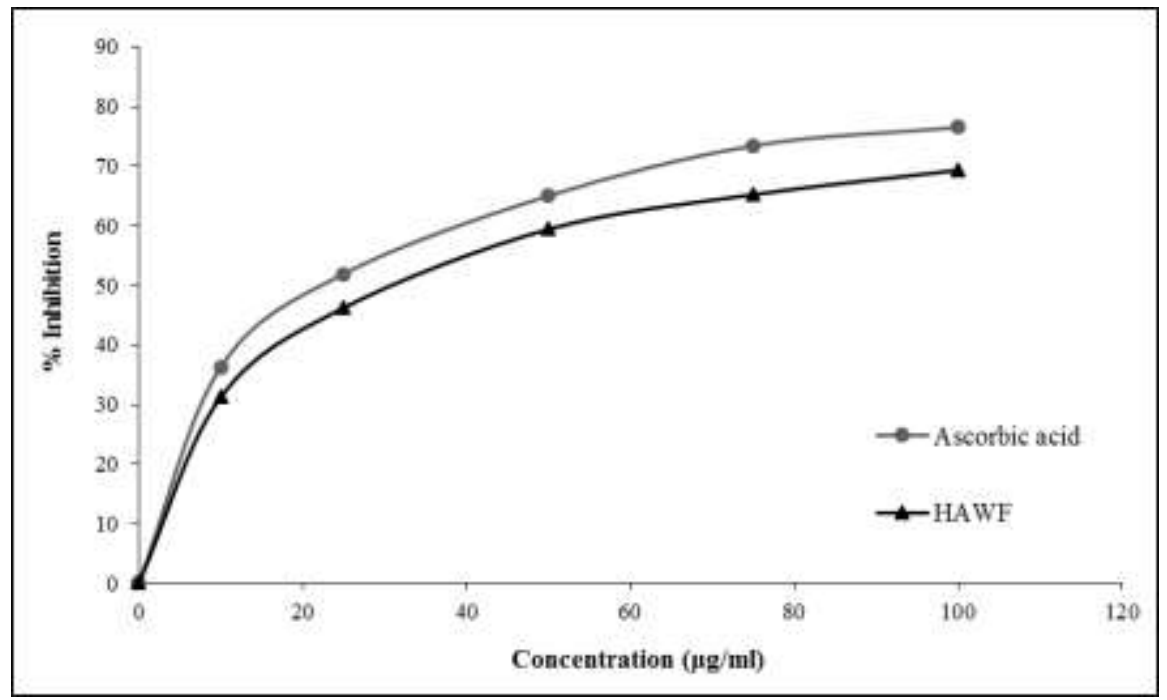

Figure 3: DPPH radical scavenging activity of hydroalcoholic extract of $W$. fruticosa and ascorbic acid.

\section{Ferric Reducing Antioxidant Power (FRAP)}

In this experiment the extract/standard changes color from pale yellow/white to greenish-blue or dark blue depending on the concentration. The color change is due to the presence of an antioxidant group present in the plant which reduces ferricyanide $\left(\mathrm{Fe}^{2+}\right)$ to ferrocyanide $\left(\mathrm{Fe}^{3+}\right)$ and when the ferric chloride was added, the ferric-ferrous complex was formed which will be measured at $700 \mathrm{~nm}$. The reducing power assay of plant extract/standard increases with concentration, Figure 4 represents the reducing power assay of both standard and extract, fromthis figure it is concluded that the reducing power assay of HAWF is lesser than standard (Ascorbic acid) but it contains the compound which is responsible for antioxidant activity.

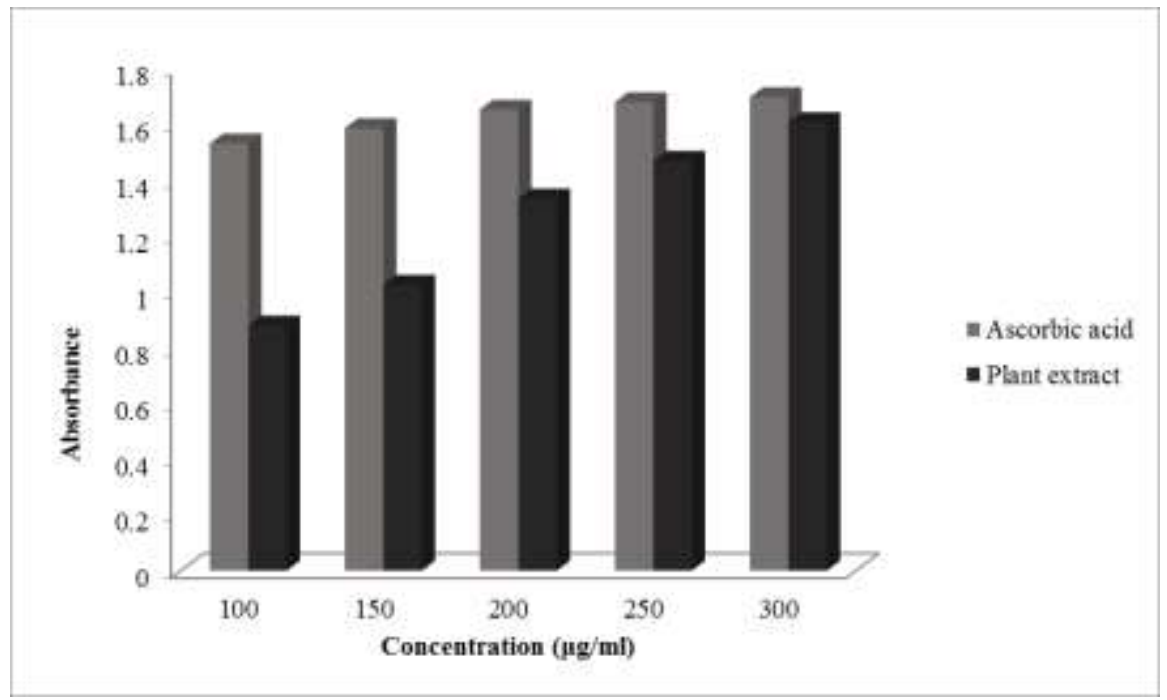

Figure 4. Reducing power assay of HAWF and ascorbic acid at different concentrations.

\section{In vitro Antidiabetic activity}

\section{$\alpha$-amylase Inhibition Assay}

The $\alpha$-amylase breakdown the starch and responsible for the production of glucose, hence when this enzyme activity is controlled it help to overcome the postprandial hyperglycemia. The $\alpha$-amylase inhibitory activity was measured in HAWFand acarbose, from that it was observed that acarbose has higher activity than the extract with the increase in concentration. The anti- $\alpha$-amylase activity of HAWF and acarbose is presented in Figure 5. HAWF showed significant $(\mathrm{p}<0.01)$ anti- $\alpha$-amylase activity $\left(\mathrm{IC}_{50}=64.27 \pm\right.$ $1.47 \mu \mathrm{g} / \mathrm{ml}$ ) compared to standard inhibitor acarbose ( IC $_{50}=$ $58.56 \pm 1.23$ ). 


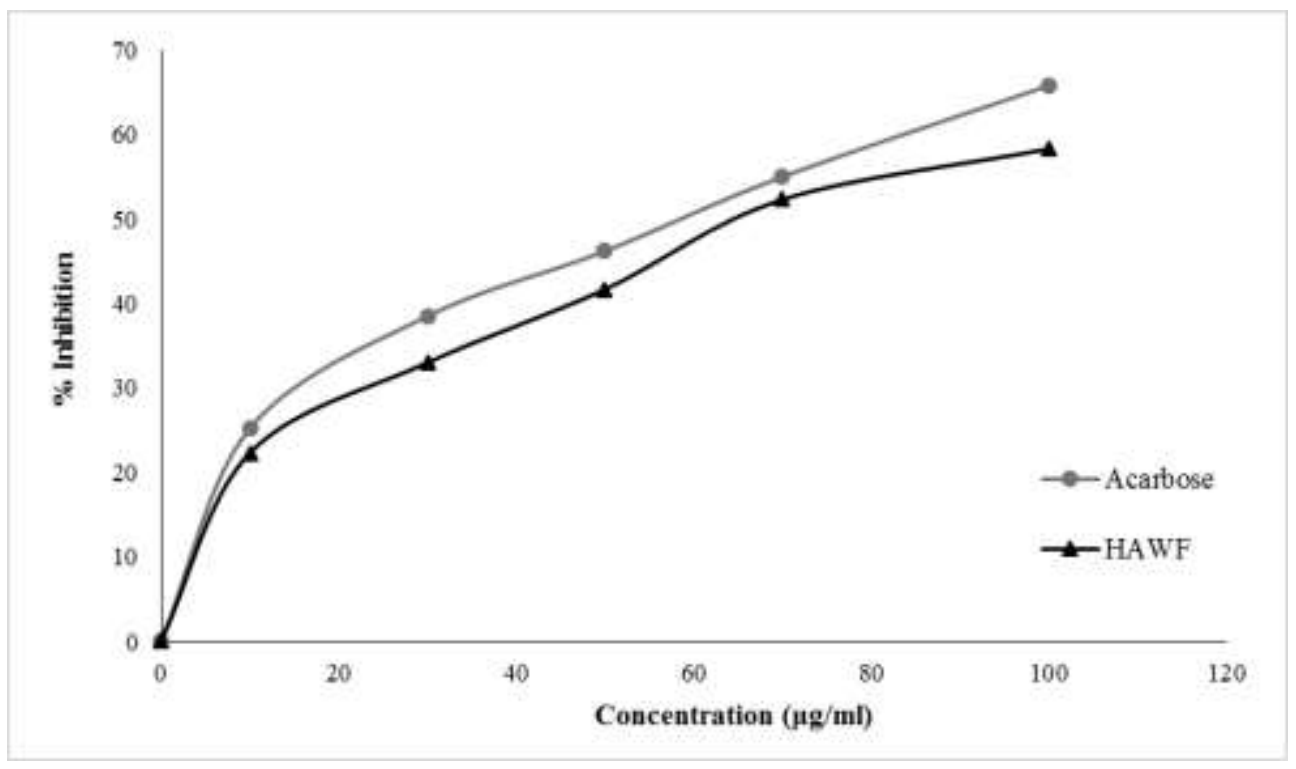

Figure 5. $\alpha$-amylase inhibitory effect of hydroalcoholic extract of $W$. fruticosa.

\section{$\alpha$-glucosidase Inhibition assay}

The plant contains various flavonoid groups which are considered to be responsible for inhibition of $\alpha$-glucosidase activity, the glucosidase was mainly responsible for the breakdown of starch and is considered to be responsible for type 2 diabetes. Hence the HAWF was examined for this $\alpha$ glucosidase activity which was found that the activity of $\alpha$ - glucosidase has been reduced more as compared to the reference compound i.e acarbose with the increase in its extract concentration. The $\alpha$-glucosidase inhibitory activity of HAWF and acarbose is presented in Figure 6 . The $\alpha$ glucosidase inhibitory activity of HAWF $\left(\mathrm{IC}_{50}=71.53 \pm 1.37\right.$ $\mu \mathrm{g} / \mathrm{ml} \mu \mathrm{g} / \mathrm{ml}$ ) was significant $(\mathrm{p}<0.01)$ compared to standard inhibitor acarbose (IC $50=51.96 \pm 0.87$ ).

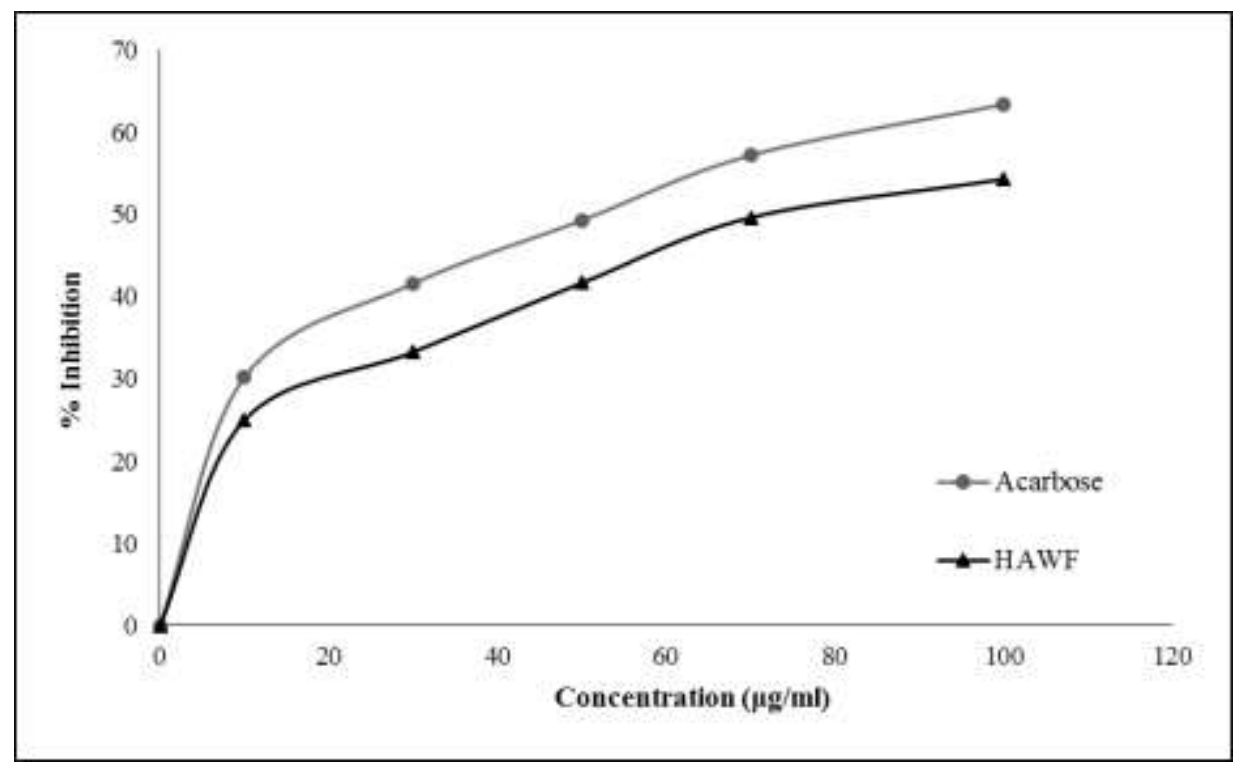

Figure 6. $\alpha$-glucosidase inhibitory effect results of hydroalcoholic extract of $W$. fruticosa.

\section{CONCLUSION}

Phytochemical investigation $W$. fruticosa flower confirmed the presence of flavonoid, alkaloid, carbohydrate, tannin, glycoside, and triterpenoid compounds. In this experiment, it was found there is the presence of flavonoid groups and phenolicgroup of compounds in the flower of $W$. fruticosa. The presence of these compounds are responsible for the entrapment of free radical and act as a natural antioxidant as well as have antidiabetic activity of the flower of $W$. fruticosa. This evaluation helps in the investigation of compounds that may help combat many harmful diseases.
HAWF showed potent antioxidant activity by inhibiting DPPH. The reducing power of the extract increased with the increasing amount of sample. In addition, the extract was found to contain a significant amount of total phenols and flavonoids, which play a major role as antioxidants. It also showed effective antidiabetic activity by inhibiting $\alpha$-amylase and $\alpha$-glucosidase. Thus the $\alpha$-amylase and $\alpha$-glucosidase inhibitory activity may be due to the presence of polyphenolics in the extract which have been identified earlier. 


\section{ACKNOWLEDGMENT}

The authors sincerely acknowledge the University of North Bengal, West Bengal, India.

\section{CONFLICTS OF INTEREST}

The authors declare that they have no conflict of interest.

\section{REFERENCES}

1. Ekor M. The growing use of herbal medicines: issues relating to adverse reactions and challenges in monitoring safety. Frontiers in pharmacology, 2014; 10(4):177. DOI: https://doi.org/10.3389/fphar.2013.00177

2. Saxena M, Saxena J, Nema R, Singh D, Gupta A. Phytochemistry of medicinal plants. Journalof pharmacognosy and phytochemistry. $2013 ; 1: 1(6)$

3. Chen J, Mangelinckx S, Adams A, Wang ZT, Li WL, De Kimpe N. Natural flavonoids as potential herbal medication for the treatment of diabetes mellitus and its complications. Natural product communications. 2015; 10(1):187-200. DOI: https://doi.org/10.1177/1934578X1501000140

4. GBIF (Global Biodiversity Information Facility). GBIF secretariat: GBIF backbone taxonomy. available at https://www.gbif.org/species/5635525. Accessed December 5, 2021.

5. Das PK, Goswami S, Chinniah A, Panda N, Banerjee S, Sahu NP, Achari B. Woodfordia fruticosa: Traditional uses and recent findings. Journal of Ethnopharmacology. 2007 Mar 21; 110(2):189-99. DOI: https://doi.org/10.1016/j.jep.2006.12.029

6. Baravalia Y, Vaghasiya Y, Chanda S. Brine shrimp cytotoxicity, anti-inflammatory and analgesic properties of Woodfordia fruticosa Kurz flowers. Iranian journal of pharmaceutical research: IJPR. 2012; 11(3):851

7. Khan IA, Singh A, Mindala DP, Meena S, Vij B, Yadav AK, Roy S, Nandi U, Katare AK, Jaglan S, Singh D. Preclinical development of gastro-protective botanical candidate from Woodfordia fruticosa (Linn.) Kurz: Chemical standardization, efficacy, pharmacokinetics and safety pharmacology. Journal of ethnopharmacology. 2019 Sep 15; 241:112023. DOI: https://doi.org/10.1016/j.jep.2019.112023

8. Chandan BK, Saxena AK, Shukla S, Sharma N, Gupta DK, Singh K, Suri J, Bhadauria M, Qazi GN. Hepatoprotective activity of Woodfordia fruticosa Kurz flowers against carbon tetrachloride induced hepatotoxicity. Journal of ethnopharmacology. 2008 Sep 26; $119(2): 218-24$ https://doi.org/10.1016/j.jep.2008.06.020

9. Chaturvedi PA, Ghatak AA, Desai NS. Evaluation of radical scavenging potential and total phenol content in Woodfordia fruticosa from different altitudes. Journal of plant biochemistry and biotechnology. 2012 Jan; 21(1):17-22. DOI: https://doi.org/10.1007/s13562-011-0066-1

10. Raghuvanshi R, Nuthakki VK, Singh L, Singh B, Bharate SS, Bhatti $\mathrm{R}$, Bharate SB. Identification of Plant-based Multitargeted Leads for Alzheimer's Disease: In-vitro and In-vivo Validation of Woodfordia fruticosa (L.) Kurz. Phytomedicine. 2021 Jul
21:153659.

https://doi.org/10.1016/j.phymed.2021.153659

DOI:

11. Verma N, Amresh G, Sahu PK, Mishra N, Rao CV, Singh AP. Wound healing potential of flowers extracts of Woodfordia fruticosa Kurz. Indian journal of biochemistry and biophysics. 2013 Aug; 50:296-304.

12. Grover N, Meena R, Patni V. Physiochemical evaluation, phytochemical screening and chromato-graphic fingerprint profile of Woodfordia fruticosa (L.) Kurz extracts. International Journal of Pharmaceutical Sciences and Research. 2014 Jul 1; $5(7): 2772$.

13. Yadav M, Chatterji S, Gupta SK, Watal G. Preliminary phytochemical screening of six medicinal plants used in traditional medicine. Int J Pharm Pharm Sci. 2014; 6(5):539-42.

14. Ikram EH, Eng KH, Jalil AM, Ismail A, Idris S, Azlan A, Nazri HS, Diton NA, Mokhtar RA. Antioxidant capacity and total phenolic content of Malaysian underutilized fruits. Journal of food Composition and Analysis. 2009 Aug 1; 22(5):388-93. DOI: https://doi.org/10.1016/j.jfca.2009.04.001

15. Aryal S, Baniya MK, Danekhu K, Kunwar P, Gurung R, Koirala N. Total phenolic content, flavonoid content and antioxidant potential of wild vegetables from Western Nepal. Plants (Basel). 2019 Apr 11; 8(4):96. https://doi.org/10.3390/plants8040096

16. Mensor LL, Menezes FS, Leitão GG, Reis AS, Santos TC, Coube CS, Leitão SG. Screening of Brazilian plant extracts for antioxidant activity by the use of DPPH free radical method. Phytotherapy research. $2001 \quad$ Mar; 15(2):127-30. DOI: https://doi.org/10.1002/ptr.687

17. Oyaizu M. Studies on products of browning reaction antioxidative activities of products of browning reaction prepared from glucosamine. The Japanese journal of nutrition and dietetics. 1986; 44(6):307-15.

18. Apostolidis E, Lee CM. In vitro potential of Ascophyllum nodosum phenolic antioxidant- mediated $\alpha$-glucosidase and $\alpha$-amylase inhibition. Journal of food science. 2010 Apr; 75(3):H97-102. DOI: https://doi.org/10.1111/j.1750-3841.2010.01544.x

19. Shu XS, Lv JH, Tao J, Li GM, Li HD, Ma N. Antihyperglycemic effects of total flavonoids from Polygonatum odoratum in STZ and alloxan-induced diabetic rats. Journal of ethnopharmacology. 2009 Jul 30; 124(3):539-43. DOI: https://doi.org/10.1016/j.jep.2009.05.006

20. Mechchate H, Es-Safi I, Louba A, Alqahtani AS, Nasr FA, Noman OM, Farooq M, Alharbi MS, Alqahtani A, Bari A, Bekkari H. In Vitro Alpha-Amylase and Alpha-Glucosidase Inhibitory Activity and In Vivo Antidiabetic Activity of Withania frutescens L. Foliar Extract. Molecules. 2021 Jan; 26(2):293. DOI: https://doi.org/10.3390/molecules26020293

21. Alqahtani AS, Hidayathulla S, Rehman MT, ElGamal AA, AlMassarani S, Razmovski-Naumovski V, Alqahtani MS, El Dib RA, AlAjmi MF. Alpha-Amylase and alpha-glucosidase enzyme inhibition and antioxidant potential of 3-Oxolupenal and Katononic Acid Isolated from Nuxia oppositifolia. Biomolecules. 2020 Jan; 10(1):61. DOI: https://doi.org/10.3390/biom 10010061 